\title{
RECENT RECORDS OF LARGETOOTH SAWFISH PRISTIS PRISTIS (LINNAEUS, 1758) FROM PARERHAT OF PIROJPUR DISTRICT IN THE SOUTHWESTERN BANGLADESH
}

\author{
Gawsia Wahidunnessa Chowdhury*, Sabrina Sabbir and Alifa Bintha Haque \\ Department of Zoology, University of Dhaka, Dhaka-1000, Bangladesh
}

\begin{abstract}
Sawfishes are the most endangered cartilaginous fishes on earth with alarming global population decline due to by-catch and socio-economic value. A study on elasmobranch diversity in one of the landing sites of Bangladesh observed annual sawfish captures $(n=5)$ adjacent to the Sundarbans, the largest mangrove forests in the world, between June 2017 and March 2018. Only largetooth sawfish Pristis pristis was recorded in this study. Data were collected from interviews with fishermen, literature review, media reports and through monthly fish landing record sheet used during the study period. Findings of this study shows that $80 \%(\mathrm{n}=4)$ sawfish species were captured in dry season (November to March) and 20\% $(n=1)$ in wet season (June to October). Findings from the semi-structured interviews $(n=50)$ reported that $54 \%$ of the respondents were not aware of the value (ecological as well as economic) of sawfish species whereas $46 \%$ of the respondents mentioned sawfish as an important species as its flesh used to cure cancer. Although this report does not reflect the annual capture of sawfish from all over the country, this catch pattern is alarming and needs immediate action to develop a monitoring programme to assess sawfish landings in this area. Priority research is also needed to understand sawfish life history, identify their critical habitats and raise awareness to conserve sawfish species.
\end{abstract}

Key words: By-catch, conservation, Pristis pristis, sawfish distribution

\section{INTRODUCTION}

Pristidae (a group of benthic elasmobranchs) has been categorized as an exceptionally threatened family of fishes on earth due to anthropogenic impacts (Harrison and Dulvy 2014, Dulvy et al. 2016). All the five sawfish species are facing different categories of threats (CITES 2013, Dulvy et al. 2016). Sawfishes are distributed in shallow, sandy or muddy bottoms across the coastal areas, estuaries and freshwaters from the tropical to sub-tropical regions (Roy et al. 2012, Faria et al. 2013, Feitosa et al. 2017). Sawfishes are identified as a very large shark-like rays and are able to tolerate a wide range of salinities specially mangroves (Harrison and Dulvy 2014, Leeney 2017).

Sawfishes possess a large saw-shaped rostrum, that can be up to onequarter of its total body length, which makes them the unique elasmobranch of the ocean (Harrison and Dulvy 2014). They use the rostrum to capture benthic prey,

*Corresponding author: <gawsia@gmail.com>, <gawsia@du.ac.bd>

(C) 2018 Zoological Society of Bangladesh DOI: http://dx.doi.org/10.3329/bjz.v46i2.39057 
which includes fish, shrimp, and other bottom-dwelling invertebrates (Harrison and Dulvy 2014, Feitosa et al. 2017). However, the rostrum is responsible for their entanglement in the fishing nets (Dulvy et al. 2016, Feitosa et al. 2017).

Sawfish species were common in the Ganges and other rivers (Simpfendorfer et al. 2010; Haque et al. 2018). Currently the data on sawfish occurrence and distribution are insufficient for most of the region. Till date three out of five existing sawfish species (Pristis pristis, P. zijsron and Anoxypristis cuspidata) have been reported from Bangladesh (Hossain et al. 2014, Haque et al. 2018a, Haque and Das 2018). The researchers also noticed population declines (Hossain et al. 2014).

Bangladesh is a riverine country. Its estuarine environment and largest mangrove ecosystem provided key habitats for sawfish (Roy et al. 2012; Hossain et al. 2014). Hossain et al. (2014) identified different threats and suggested a more in-depth research survey of sawfish in its critical habitats in the region. They recommended that the historical declines, range contraction and information on the occurrence and distribution and the trade dynamics should be addressed as the priority research areas.

Conservation of threatened species requires research and updated information on their occurrence, distribution and abundance (Bonfil et al. 2018). In Bangladesh, sawfish has not yet been received any conservation attention. This study aimed to provide annual sawfish occurrence and seasonality in the southwest of Bangladesh. A survey was also conducted to understand the general perception of the fishers and traders towards sawfish, its occurrence and general status.

\section{MATERIAL AND METHODS}

Study area: The study was conducted at Parerhat of Pirojpur district in the southwestern Bangladesh, located near the Sundarbans (Figure 1). An array of artisanal boats and trawlers land their daily and weekly catches from the inshore waters of Bangladesh. Although majority of the fishers do not catch sharks as a target species, they keep it as a non-discarded by-catch. There are a few boats targeting rays. A good number of boats go close to the Sundarbans to catch fish as this mangrove ecosystem is an important habitat for sawfish.

Study period: Data were recorded from field visits, questionnaire survey and from the fish landing data from June 2017 to March 2018. The study period has been divided into two seasons: wet season (June-October) and dry season (November to March).

Equipment: GPS, Camera, data record sheet, questionnaire survey sheet, species identification guide toolkit developed by the Sawfish Conservation 
Society (www.sawfishconservationsociety.org), measuring tape, weighing machine, icebox, bucket and torch were used in the field.

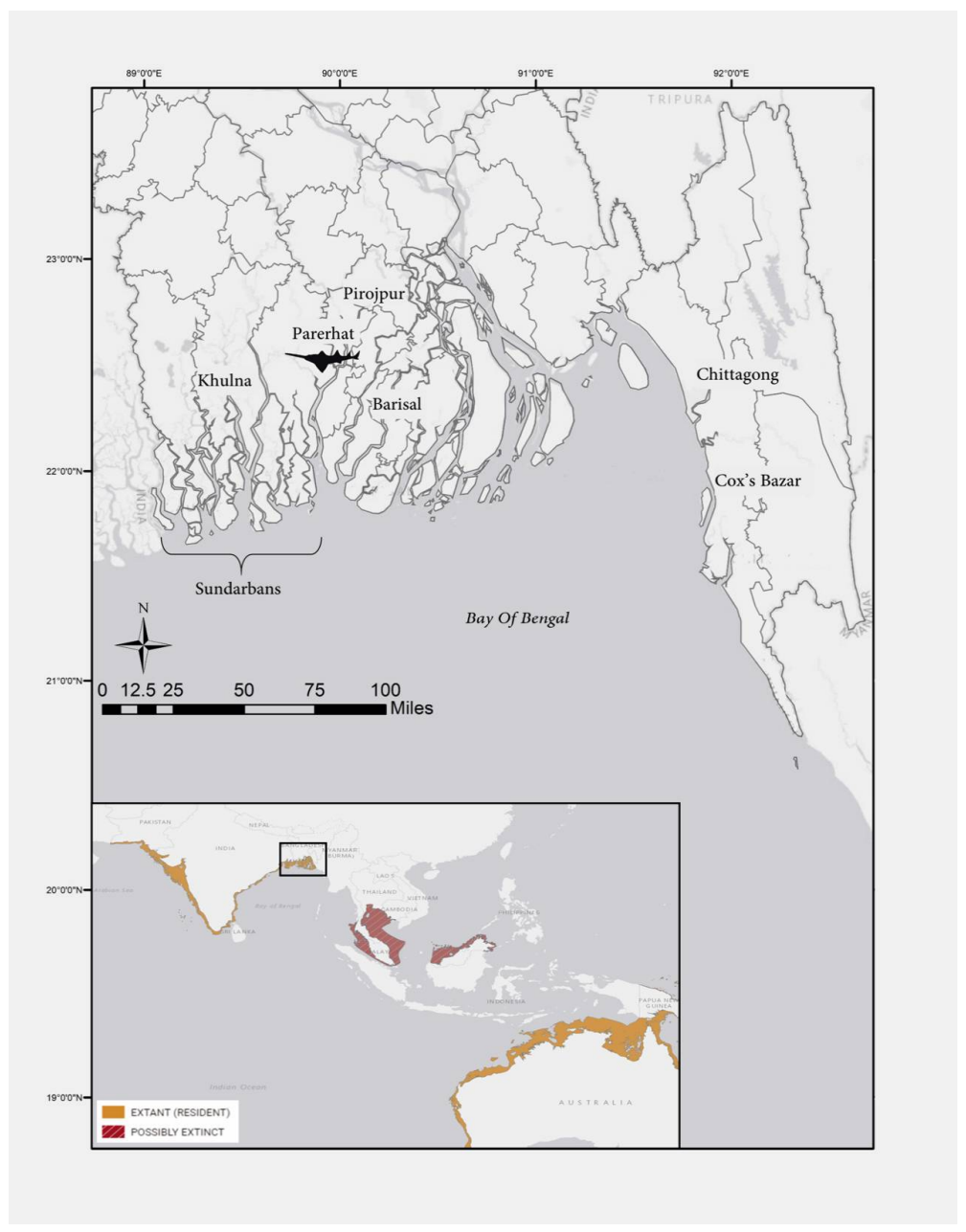

Fig. 1. Distribution range of Pristis pristis (study area within inset) according to Kyne et al. 2013. Map of study area showing the landing site in Parerhat (black: sawfish) where the sawfishes were landed and recorded during the study period.

Fish landing in the study area: A landing site was constructed in Parerhat, Pirojpur, in 2017. Bangladesh Fisheries Development Corporation (BFDC) landing centre has been constructed recently in 2018. However, traditionally the fish landing has been carried out for about 50 to 70 years in this area. This is the only fish landing station in Pirojpur district (Fig. 1), locally known as Badura Fish Landing Station, where fish landings occur all year round. 
The river that flows within the Badura Fish Landing Station commonly known as "Kocha". Nearly 30-50 artisanal fishing trawlers bring fish from the sea at this Badura Landing Station usually on Fridays, Saturdays or Sundays. Fish Market begins from 7 am to 9 am. Recorded specimens were identified following Faria et al. (2013) and the toolkit developed by the Sawfish Conservation Society (www.sawfishconservationsociety.org). Life stage was estimated following Last et al. (2016).

Questionnaire survey: A total of about 50 persons including fishermen and fish traders were interviewed using questionnaires regarding sawfish captures. Questions were related to sawfish encounter, estimated total length, estimated weight, importance of sawfish, use of sawfish, location and year of capture, gear used to capture, etc. Respondents were identified as knowledgeable for the interview session by the local fishermen. All respondents were identified as fishers and traders. Their age ranged from 25 to 65 years and fishing experience varied from 10-50 years (mean $=30.62$ ). Interview process followed snowball technique whereby one respondent identified another one with knowledge of the related matters. Sessions were conducted in Parerhat (landing station), Balipara (a fishers' village, Fig. 1) of Pirojpur and Barguna BFDC stations. Sawfishes were easily recognized by the respondents because of their saw/rostrum and unusual size. Respondents were unable to differentiate between the species of sawfish. Following key questions were asked to assess the perception of the fishers and traders who were interviewed:

1. Have you encountered sawfish in your lifetime?

2. Are you aware of the importance of the sawfish?

3. Do you think sawfish has been captured as bycatch?

4. Have you retained captured sawfish for sale?

5. Do you think sawfish number in this area has been declining?

Data analysis: Data were organized, tabulated and analysed in excel spreadsheet.

\section{RESULTS AND DISCUSSION}

From June 2017 to March 2018, only one species, large tooth sawfish Pristis pristis was recorded (Fig. 2).

A total of five large tooth sawfish were recorded (Table 1). There is a strong seasonality to sawfish captures in the southwest, $80 \%$ recorded in dry period (November to March) when water levels remain lowest, followed by wet period (June-October) (20\%). 
Hossain et al. (2014) also reported that sawfish are encountered in Bangladesh during the winter. During the dry period, water level remains low that makes sawfish susceptible to fishing. Moreover, there is more fishing observed during the dry period of the year.

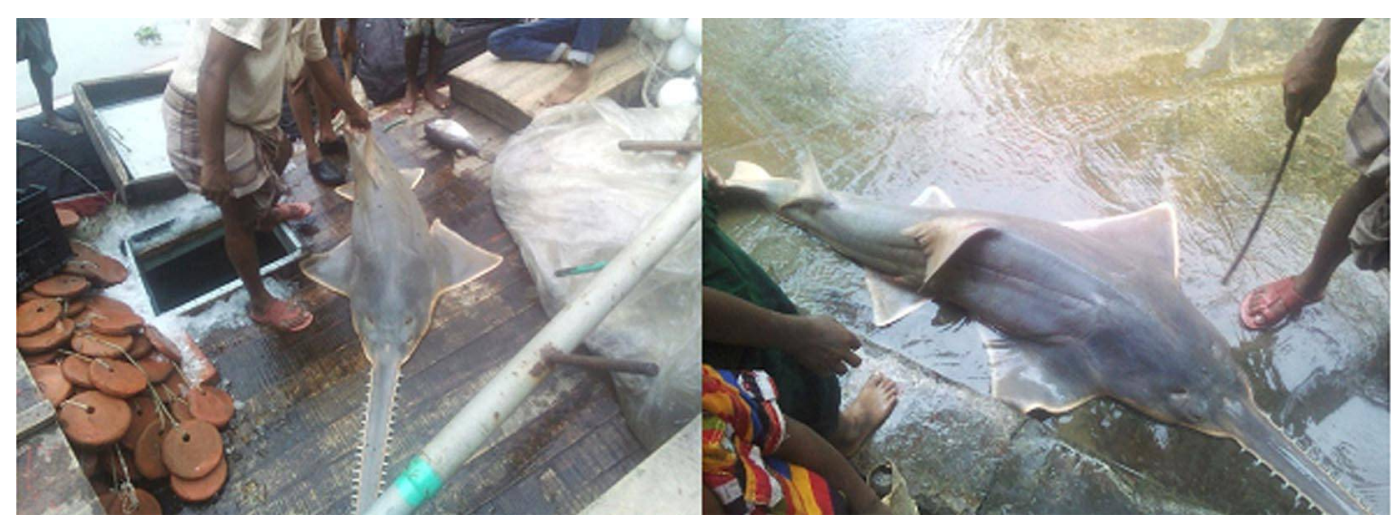

Fig. 2. Largetooth sawfish Pristis pristis, recorded on 5 August 2017.

Table 1. Largetooth Sawfish, Pristis pristis, recorded during the study period with biological data and important notes on socio-economic value and trade

\begin{tabular}{|c|c|c|c|c|c|c|c|}
\hline $\begin{array}{l}\text { Sl. } \\
\text { No. }\end{array}$ & $\begin{array}{l}\text { Evidence of } \\
\text { record }\end{array}$ & $\begin{array}{l}\text { Record } \\
\text { (month) }\end{array}$ & $\begin{array}{l}\text { Life } \\
\text { stage }\end{array}$ & $\begin{array}{l}\mathrm{TL} \\
(\mathrm{cm})\end{array}$ & $\begin{array}{l}\mathrm{RL} \\
(\mathrm{cm})\end{array}$ & $\begin{array}{l}\text { Weight } \\
(\mathrm{kg})\end{array}$ & Remark/s \\
\hline 1. & $\begin{array}{l}\text { Recorded } \\
\text { from field \& } \\
\text { photo }\end{array}$ & $\begin{array}{l}\text { February } \\
2017\end{array}$ & Juvenile & 81 & 19 & 8 & $\begin{array}{l}\text { It was caught by the } \\
\text { fishers as by-catch and } \\
\text { locally sold }\end{array}$ \\
\hline 2. & $\begin{array}{l}\text { Recorded } \\
\text { from field }\end{array}$ & $\begin{array}{l}\text { February } \\
2017\end{array}$ & Juvenile & 91 & 22 & 9 & $\begin{array}{l}\text { By-catch. Recorded with } \\
\text { poor quality photo }\end{array}$ \\
\hline 3. & $\begin{array}{l}\text { Recorded } \\
\text { from field }\end{array}$ & $\begin{array}{l}\text { August } \\
2017\end{array}$ & Juvenile & 97 & 23.5 & 10 & By-catch \\
\hline 4. & $\begin{array}{l}\text { Recorded } \\
\text { from field }\end{array}$ & $\begin{array}{l}\text { August } \\
2017\end{array}$ & Juvenile & 132 & 32 & 13 & $\begin{array}{l}\text { By-catch. Per kg of } \\
\text { meat was sold } 3000- \\
5000 \text { BDT }\end{array}$ \\
\hline 5. & $\begin{array}{l}\text { Recorded } \\
\text { from field }\end{array}$ & $\begin{array}{l}\text { October } \\
2017\end{array}$ & Juvenile & 183 & 45 & 50 & $\begin{array}{l}\text { Sold at } 5000 \text { BDT per } \mathrm{kg} \\
\text { of meat }\end{array}$ \\
\hline
\end{tabular}

Specimens varied in size between 81 and $183 \mathrm{~cm}$ TL with weight ranges between 8 and $50 \mathrm{~kg}$ (mean $=18$ ) (Table 1). All recorded sawfishes were juveniles presumably caught mainly near the inshore areas (Simpfendorfer, 2010, Poulakis et al. 2011, Hossain et al. 2014) of the southwestern part of the country. Life stage of the specimens was recognized as juvenile by following Last et al. (2016). This finding supports the similar findings by Hossain et al. (2014) which reported Sundarbans as a critical nursery habitat for juvenile sawfish. 
Information collected from the respondents also showed that the critically endangered sawfish in the southwest of Bangladesh is under serious threat. Most (90\%) of the respondents have seen sawfish in winter which also supported the direct observations during this study and Hossain et al. (2014) also reported the strong seasonal pattern of sawfish.

All the respondents opined that sawfish occurrence in current days has been declining. About 60\% respondents stated that the captured sawfish were retained for sale in the local market. Among 95\% respondents mentioned that sawfish were captured as by-catch. Among the respondents $54 \%$ were not aware of the importance (ecological and economic) of sawfish whereas $46 \%$ respondents strongly believe that sawfish is an important species. About $90 \%$ of the respondents encountered sawfish in their lifetime.

There were variations in the weights of sawfish as per the statements of the respondents who have encountered sawfish in their lifetime: $70 \%$ said $10-20 \mathrm{~kg}$, $20 \%$ said $+25 \mathrm{~kg}$ and 5\% said they could not remember the weight. Among the respondents the total length also varied, $85 \%$ said the lengths were about $3.0 \mathrm{~m}$ where as $15 \%$ said that the length was $<3.0 \mathrm{~m}$.

Hossain et al. (2014) and Bonfil (1994) reported that the sawfish are caught as a by-catch from other fisheries by using bottom and drift gill nets. According to Dulvy et al. (2016) and Feitosa et al. (2017), sawfish are susceptible to bycatch through entanglement of their rostra in the net, which also supported by the statement of the respondents $(95 \%)$.

Findings from current study indicate the gap in implementation of legal tools to conserve this critically endangered species. Lack of awareness and monitoring by the authority are also identified as threats in this study, which is also identified as threats globally (Dulvy et al. 2016, Feitosa et al. 2017, Haque et al. 2018).

The price of the sawfish varied greatly during study period, which ranged from 3000 to 5000 BDT. This study reported that the price depends on the size of the saw which supports the findings of Hossain et al. (2014).

Major threats were identified as lack of awareness, unrestricted exploitation and data deficiency. As this study recorded all the juvenile sawfishes captured as by-catch, it raised an alarm for local population extinction of this critically endangered species (Hossain et al. 2014, Dulvy et al. 2016). Existence of this critically endangered sawfish species is under threat of unrestricted exploitation. Critical habitat of this species needs to be monitored requires attention. The findings of this study identified the gap of monitoring fishing and landings in the southwestern part of Bangladesh. According to Haque et al. (2018a,) lack of monitoring is the evidence that CITES-listed shark and ray species in 
Bangladesh are protected on paper only and remain, as the major cause for the undocumented international trade in some ray and shark species.

Conservation actions are ignored by increasing fishing pressure, habitat destruction, lack of knowledge about laws, lack of monitoring by the authority. Findings indicate that this critically endangered species needs priority research in this area. Biology, ecology, population size, genetic diversity, sex ratio, movement patterns and habitat use data are vital to understand this particular species.

\section{CONCLUSIONS}

The recorded sawfish species, $P$. pristis, is protected by Wildlife (Preservation and Security) Act 2012 in Bangladesh and catch and trade are prohibited (CITES 2013, IUCN 2013), yet exploitation and trade rates are high, which require proper monitoring. Although there are legal tools in place for the protection of this species, the fishers and traders are not fully aware of these. They are even unaware of the ecological importance of sharks. Considering the values of the sawfish and considering the present threats to it is recommended that a conservation action plan be in place as soon as possible.

Acknowledgements: The authors are grateful to all the fishers and locals for helping with valuable information, and the Department of Zoology, University of Dhaka, for hosting the research work. Authors are grateful to WildTeam for providing support to field trips. Authors are also thankful to Mr Nazmul Hasan for preparing the map.

\section{LITERATURE CITED}

BONFIL, R. 1994. Overview of world elasmobranch fisheries. FAO Fisheries Technical Paper no. 341. Rome: FAO. 119 pp.

BONFIL, R., SORIANO, R.M, OSCAR, U.M.V., LOEZA, I.M., JUAN, C.P.J., NATALY, B.M. and PAOLA, P.B. 2018. Trapping into local ecological knowledge to assess the former importance and current status of sawfish in Mexico. Endanger. Species Res. 36: 213-228.

CITES (Convention on International Trade in Endangered Species of Wild Fauna and Flora). 2013. Fifteenth meeting of the Conference of the Parties. Doha (Gatar), 13-25 March 2010. CoP15 Doc. $53,14 \mathrm{p}$.

DULVY, N.K., DAVIDSON, L.N., KYNE, P.M., SIMPFENDORFER, C.A., HARRISON, L.R., CARLSON, J.K. and FORDHAM, S.V. 2016. Ghosts of the coast: global extinction risk and conservation of sawfishes. Aquat. Conserv. 26(1): 134-153.

FARIA, V.V., MCDAVITT, M.T., CHARVET, P., WILEY, T.R., SIMPFENDORFER, C.A. and NAYLOR, G.J. 2013. Species delineation and global population structure of Critically Endangered sawfishes (Pristidae). Zool. J. Linnean Soc. 167(1): 136-164.

FEITOSA, L.M., MARTINS, A.P.B. and NUNES, J.L.S. 2017. Sawfish (Pristidae) records along the Eastern Amazon coast. Endanger. Species Res. 34: 229-234. 
HAQUE, A.B., BISWAS, A. and LATIFA, G.A. 2018a. Observations of shark and ray products in the processing centres of Bangladesh, trade in CITES species and conservation need. TRAFFIC Bulletin. 30(1). University of Cambridge, UK.

HAQUE, A.B. and DAS, S.A. 2018b. First confirmed record of the Critically Endangered green sawfish Pristis zijsron from Bangladeshi waters. J. Fish Biol. (in press).

HARRISON, L.R. and DULVY, N.K. (eds.). 2014. Sawfish: a global strategy for conservation. IUCN Species Survival Commission's Shark Specialist Group. Canada: Vancouver.

HOSSAIN, M.A., THOMPSON, B.S., CHOWDHURY, G.W., MOHSANIN, S., FAHAD, Z.H., KOLDEWEY, H.J. and ISLAM, M.A. 2014. Sawfish exploitation and status in Bangladesh. Aquat. Conserv. 25(6): 781-799.

IUCN. 2013. IUCN Red List of Threatened Species. http:// www.iucnredlist.org (6 November 2018)

KYNE, P.M., CARLSON, J. and SMITH, K. 2013. Pristis pristis. The IUCN Red List of Threatened Species 2013: e.T18584848A18620395. http://dx.doi.org/10.2305/IUCN.UK.2013-1.RLTS.T1 8584848A18620395.en. Downloaded on 23 November 2018.

LAST, P., WHITE, W., SERET, B., NAYLOR, G., DECARVALHO, M. and STEHMANN, M. (eds.). 2016. Rays of the world. CSIRO Publishing, Clayton South.

LEENEY, R.H. 2017. Are sawfishes still present in Mozambique? A baseline ecological study. Peer J 5:e2950; DOI 10.7717/peerj.2950.

ROY, B.J., NRIPENDRA K.S. and GAZIUR R.M. 2012. Availability of vulnerable elasmobranches in the marine water of Bangladesh. Bangladesh J. Zool. 40: 221-229.

SIMPFENDORFER, C.A., WILEY, T.R. and YEISER, B.G. 2010. Improving conservation planning for an endangered sawfish using data from acoustic telemetry. Biol. Cons. 143: 1460-1469. 